\title{
Muscle strengths and nutritional considerations after coronary bypass surgery in patients with diabetes mellitus and controls
}

\author{
Mijana Barišićl*, \\ Viktor Peršić1,2, \\ Damir Raljević', \\ Marica Komošar- \\ Cvetković', \\ Aleksandar Včev², \\ Marko Boban ${ }^{1,2}$ \\ ${ }^{1}$ Thalassotherapia Opatija \\ - Clinic for treatment, \\ rehabilitation and prevention \\ of cardiovascular disease, \\ Opatija, Croatia \\ ${ }^{2}$ Josip Juraj Strossmayer \\ University of Osijek School \\ of Medicine, University \\ Hospital Centre Osijek, \\ Osijek, Croatia
}

RECEIVED:

July 31, 2015

ACCEPTED:

September 17, 2015
KEYWORDS: cardiac rehabilitation, hand grip test, nutritional risk screening, unintentional loss of weight. CITATION: Cardiol Croat. 2015;10(9-10):219. | DOI: http://dx.doi.org/10.15836/ccar.2015.219

*ADDRESS FOR CORRESPONDENCE: Mijana Barišić, Thalassotherapia Opatija, M. Tita 188/1, HR-51410 Opatija, Croatia. Phone: 385-91-7201137 / E-mail: mija3007@gmail.com

ORCID: Mijana Barišić, http://orcid.org/0000-0001-5774-7488 • Viktor Peršić, http://orcid.org/0000-0003-4473-5431 Damir Raljević, http://orcid.org/0000-0001-9743-9201 • Marica Komošar-Cvetković, http://orcid.org/0000-0002-9539-9733 Marko Boban, http://orcid.org/0000-0002-6129-575X

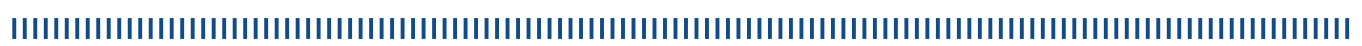

INTRODUCTION: Major invasive treatment, like cardiac surgery leads to muscle weakness, unintentional weight loss and increased nutritional risk. ${ }^{1-3}$ The aim of our study was to assess these parameters in patients scheduled for cardiac rehabilitation after recent heart surgery, depending on the existence of diabetes mellitus.

PATIENTS AND METODS: Prospective study that included patients with diabetes scheduled for rehabilitation within one month from surgical procedure, and control number of peers without diabetes. Assessment included anthropometric measurement, hand grip test (HGT), weight lost history (WLH) and standardized NRS-2002 screening tool.

RESULTS: There were 59 patients of the mean age 67.0 years, male to female ratio was $48: 11$ (81\%:19\%) respectively. Diabetes mellitus was present in 26 (44\%). Diabetic vs. non diabetic had $28.7 \mathrm{~kg}$ vs. $33.5 \mathrm{~kg}$ for left hand HGT; $29.5 \mathrm{~kg}$ vs. 38.0kg for right hand HGT; \%WLH was $6.7 \%$ vs. $6.8 \%$; and NRS-2002 was 3.6 vs. 3.4, respectively.

CONCLUSION: Both groups of patients expressed similarly pronounced nutritional risk after heart surgery, measured by mean \%WLH and NRS-2002. However, a significant difference in strength of HGT implies that metabolic perturbations after surgery cause more severe muscle dysfunction in diabetics, in comparison with non-diabetics. This should be taken in to count for individualization of therapeutic approach in cardiovascular rehabilitation process.

1. Kondrup J, Allison SP, Elia M, Vellas B, Plauth M; Educational and Clinical Practice Committee, European Society of Parenteral and Enteral Nutrition (ESPEN). ESPEN guidelines for nutrition screening 2002. Clin Nutr. 2003;22(4):415-21. DOI: http://dx.doi.org/10.1016/S0261-5614(03)00098-0

2. Boban M, Laviano A, Persic V, Rotim A, Jovanovic Z, Vcev A. Characteristics of NRS-2002 Nutritional Risk Screening in patients hospitalized for secondary cardiovascular prevention and rehabilitation. J Am Coll Nutr. 2014;33(6):466-73. DOI: http://dx.doi.org/10.1080/07315724.2013.876902

3. Boban M, Persic V, Miletic B, Kovacicek K, Madzar Z. Heart surgery stems increased nutritional risk, expressed during the course of stationary rehabilitation. Ann Nutr Metab. 2013;63(1-2):17-24. DoI: http://dx.doi.org/10.1159/000350044 